\title{
A portable suction sampler for rock epibiota
}

\author{
K. HISCOCK \& R. HOARE \\ University College of North Wales, Marine Science Laboratories; Menai Bridge, U.K.
}

KURZFASSUNG: Ein tragbarer Saugsammler für epibiotisch auf Felsen lebende Organismen. Eine Saugpumpe für bestandskundliche Untersuchungen, die von einem Taucher getragen und bedient werden kann, wird beschrieben. Sie besteht aus einer Sammelkammer, in die zwischen dem Schabrohr und der Luftsaugkammer ein Sammelnetz eingefügt wird. Die Saugkammer ist durch ein Reduktionsventil mit einem Preßluttzylinder verbunden. Mit Hilfe dieses Sammelgeräts lassen sich fast alle Organismen von Felsoberflächen entfernen. Es kann überdies auch zur quantitativen Erfassung der Fauna auf Sandböden eingesetzt werden. Vor- und Nachteile dieses Gerätes werden diskutiert.

\section{INTRODUCTION}

The collection of quantitative samples by divers investigating rock epibiota is made difficult because dislodged specimens are often dispersed by the force needed to remove them and by water movements. Suction samplers, such as that described by BARNETT \& HARDY (1967), help to overcome some of the problems encountered by divers investigating sand macrofauna. The use of similar techniques to remove epilithic organisms to a collecting bag as soon as they are dislodged should greatly increase the efficiency of taking samples.

In considering the possible modifications of the BARNETT \& HARDY sampler for use on hard bottoms, the following requirements were taken into consideration: (1) The apparatus should be portable and easily handled even in a slight current. (2) It should be possible to take several separate samples and remove each sample easily from the apparatus. (3) There should be sufficient suction to prevent detached species from falling or being swept away.

\section{DESCRIPTION OF THE APPARATUS}

A diagram of the apparatus is shown in Figure 1. The suction chamber is constructed in the manner described by BARNETT \& HARDY (1967) using ABS plastic pipe. The chamber is supplied with air at a pressure of up to seven atmospheres from a reducer valve on the compressed air cylinder. The lid of the sample chamber incorporates an " $\mathrm{O}$ " ring seal and no clamps are required since suction holds the lid in 
place. The net collecting bags have a mesh of $0.5 \mathrm{~mm}$ and a screw thread to attach them to the lid. There are corresponding screw caps to seal the bags after use. Lead trim weights were found to be necessary at the suction chamber end of the unit due to this part becoming buoyant during operation. Rigid ABS tube, layflat polythene tube and wire-wound plastic tube have been tested for use as the suction tube. The wire-wound plastic tube was found to be most satisfactory and can be folded around the apparatus during transport. The sampler presently in use weighs $25 \mathrm{~kg}$ on land and $5 \mathrm{~kg}$ in sea water.

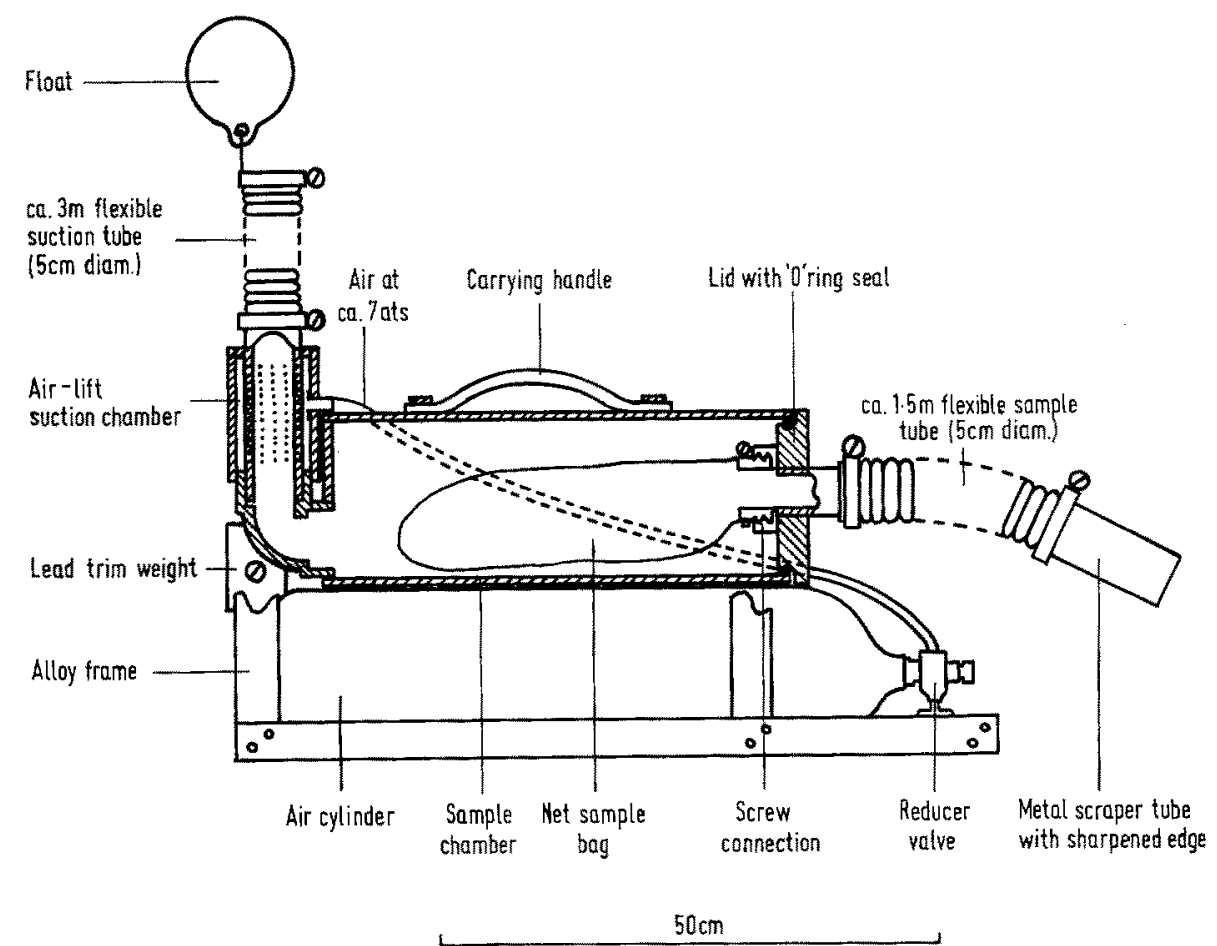

Fig. 1: The suction sampler. Suction chamber and sample chamber are shown in section

\section{OPERATION OF THE SAMPLER}

The sampler has been deployed in the following manner: The sampler is laid on the bottom or held in the hand. The quadrat is clipped into place. If any large specimens (liable to clog the sample tube) are present these are removed for later inclusion in the sample. The suction tube and sample tube are unwrapped; the float carries the suction tube to a vertical position. The air supply is turned on to produce the necessary suction (in practice it has been found unnecessary to use full suction except where organisms are being forcibly dislodged). The quadrat area is cleared with the scraper, material being sucked into the apparatus as it is loosened from the rock. When the 
sample has been taken the number of barnacle or tube worm scars can be counted or the site photographed for later counting or measurements of percentage cover. The sample bag is removed and capped. Another bag is then screwed into place ready for the next sample. (The use of an adjustable buoyancy lifejacket is essential during this work.)

The area which can be sampled with one cylinder of air will depend on the amount and type of material being collected, the capacity of the air cylinder, the force of suction required and the depth at which the sampler is being used. However, during early experiments when the sampler was not being used to full efficiency, three $0.25 \mathrm{~m}^{2}$ samples could be taken at $15 \mathrm{~m}$ depth with a $1.6 \mathrm{~m}^{3}(57 \mathrm{cu} \mathrm{ft}) \mathrm{cylinder}$.

\section{DISCUSSION}

The advantages and disadvantages listed here refer only to the use of this appatatus when compared to other suction samplers and other methods of taking quantitative samples. In the studies carried out in which this sampler has been used, the abundance of widely dispersed species or species with a discontinuous distribution has been assessed by a different method.

A dva ntages: (1) The size and weight of the apparatus means that it is fully portable. It is easily carried, assembled and operated by one diver who can, if necessary, hold the collecting unit in one hand whilst deploying the scraper with the other. (2) The insertion of a sample bag before the suction chamber makes the unit stable and the sample bags easy to change. (3) None of the material removed from the rock surface is lost or can escape and almost all of the biomass is collected. (4) Several samples can be taken with one air cylinder and the unit is easily adaptable for surface supply if a large area is required to be sampled at the same station. (5) The sampler can also be used for taking small samples on soft bottoms if a coarser mesh collecting bag is used. (6) The sampler can be constructed from cheap and readily available material with minimal machining.

$\mathrm{D}$ is a d vantage $s:$ (1) Large specimens included in the quadrats often have to be removed before the sampler is used. (2) Sessile organisms with a calcareous exoskeleton cemented to the rock are usually damaged on removal and the base often remains attached to the rock. Although the number of scars can be counted after the sample has been taken, it is not clear that all of the scars are of the same species or that all represent living animals. (3) The number of samples which can be taken with one cylinder is limited. (4) The apparatus cannot be used in shallow water $(<2 \mathrm{~m})$.

The principle of suction samplers lends itself to many variations and it is felt that further investigations of the method will lead to the development of further valuable tools for use in sampling the little investigated nearshore rocky sublittoral. 


\section{SUMMARY}

1. A fully portable suction sampler which can be operated by one diver is described.

2. Rock epibiota is removed by a scraper tube which leads, through a collecting chamber, to an air-lift suction chamber and tube. The sample is held in a net bag before reaching the suction chamber. Air is supplied by a cylinder incorporated into the unit.

3. The sampler removes all epilithic biota except for the parts of encrusting species cemented to the rock.

4. The sampler can also be used for sand fauna.

Acknowledgements. Our thanks are due to Mr. A. A. Q. R. McLeod who advised us during the initial design of the apparatus, to Mr. F. JACQues for his advice and assistance during the building of the apparatus, and to Mr. D. J. W. LANE for his assistance in the field trials.

\section{LITERATURE CITED}

BaRnetT, P. R. O. \& HARDY, B. L. S., 1967. A diver-operated quantitative bottom sampler for sand macrofaunas. Helgoländer wiss. Meeresunters, 15, 390-398.

First author's address: K. Hrscock

Marine Science Laboratories

Menai Bridge, Anglesey,

U. K. 